\title{
Correction to: Optimization of pediatric CT scans in a developing country
}

Eddy Fotso Kamdem ${ }^{1 *}$, Odette Ngano Samba ${ }^{1,2}$, Clemence Alla Takam ${ }^{1}$, Alain Jervé Fotue ${ }^{1}$, Serge Abogo ${ }^{3}$ and Cornellius Lukong Fai ${ }^{1}$

\section{Correction to: BMC Pediatr 21, 44 (2021) \\ https://doi.org/10.1186/s12887-021-02498-2}

Following the publication of the original article [1], the Conflict of interest statement tagging does not follow tagging guidelines to include an attribute to make it machine-readable.

Tagging error. The $<$ DataAvailability $>$ element includes the Data Availability, Ethics, Consent for publication, and Competing Interests statements.

An <Ethics> element is missing; it should hold the Ethics, Consent for publication, and Competing interests statements.

The original article has been corrected.

\section{Author details}

'Department of Physics, Faculty of Science, Unité de Recherche de la Matière Condensée, d'Electronique et de Traitement du Signal, University of Dschang, Dschang, Cameroon. ${ }^{2}$ Radiography Department, Yaoundé General Hospital, Yaoundé, Cameroon. ${ }^{3}$ Department of Radiology, National Social Insurance Fund Hospital, Yaoundé, Cameroon.

Published online: 24 February 2021

\section{Reference}

1. Kamdem FE, Ngano SO, Alla Takam C, et al. Optimization of pediatric CT scans in a developing country. BMC Pediatr. 2021;21:44. https://doi.org/10.11 86/s1 2887-021-02498-2.

\footnotetext{
The original article can be found online at https://doi.org/10.1186/s12887021-02498-2.

* Correspondence: eddyfotsokamdem@yahoo.fr

'Department of Physics, Faculty of Science, Unité de Recherche de la Matière Condensée, d'Electronique et de Traitement du Signal, University of Dschang, Dschang, Cameroon

Full list of author information is available at the end of the article
}

(C) The Author(s). 2021 Open Access This article is licensed under a Creative Commons Attribution 4.0 International License, which permits use, sharing, adaptation, distribution and reproduction in any medium or format, as long as you give appropriate credit to the original author(s) and the source, provide a link to the Creative Commons licence, and indicate if changes were made. The images or other third party material in this article are included in the article's Creative Commons licence, unless indicated otherwise in a credit line to the material. If material is not included in the article's Creative Commons licence and your intended use is not permitted by statutory regulation or exceeds the permitted use, you will need to obtain permission directly from the copyright holder. To view a copy of this licence, visit http://creativecommons.org/licenses/by/4.0/. The Creative Commons Public Domain Dedication waiver (http://creativecommons.org/publicdomain/zero/1.0/) applies to the data made available in this article, unless otherwise stated in a credit line to the data. 